\title{
POZWOLIĆ ODEJŚĆ, CZYLI... GRANICE INTERWENCJI
}

\section{BUKAL Grzegorz $^{1}$}

${ }^{1}$ dr hab. inż. arch. Grzegorz Bukal, prof. PG, Wydział Architektury Politechniki Gdańskiej e-mail: grzegorz.bukal@pg.edu.pl

https://orcid.org/0000-0001-9254-3069

ABSTRAKT: Celem tego tekstu jest zwrócenie uwagi na problem ostatecznej granicy interwencji konserwatorskich wobec zabytków architektury w kontekście holistycznej koncepcji ochrony dziedzictwa. Pełny tekst adresowany jest do polskich czytelników ze względu na szczególne odniesienia do sytuacji polskiego systemu ochrony dziedzictwa.

Choć architektura należy do sfery sztuk użytkowych, większość budynków nie powstawała jako dzieła sztuki. Racją ich bytu była i jest możliwość realizacji zadań technicznych w sposób ściśle odpowiadający oczekiwaniom użytkowników. Były w większości podporządkowane zasadom techniki i ekonomii. Ich cykl życiowy zakładał nawet estetycznie degradujące przekształcenia, zużycie oraz planowaną lub nieplanowaną śmierć. Koniec egzystencji zwykłego budynku jest tak naturalny, jak dążenie do „wiecznego”, w stanie oryginalnym, zachowania klasycznie rozumianego dzieła sztuki. Jako taki powinien być postrzegany jako naturalny, w pewnych okolicznościach nawet $\mathrm{z}$ konserwatorskiego punktu widzenia.

Polskie prawo umożliwia, poprzez bezkrytyczne przyjęcie koncepcji wszechogarniajacego „dziedzictwa”, objęcie ochroną każdego budynku pochodzącego z niezdefiniowanej „ przeszłej epoki”. Bez względu na jego stan, bez pytań o techniczną wykonalność interwencji. Wobec braku systemu obiektywnego wartościowania prowadzi to do wzrostu liczby budynków uznawanych za zabytkowe oraz nieefektywności ochrony. Pogarsza także możliwości ochrony istniejących i bardzo zaniedbanych obiektów o rzeczywistej wartości.

SŁOWA KLUCZOWE: zabytek architektury, konserwacja, interwencje konserwatorskie 


\section{Wprowadzenie}

Celem niniejszego tekstu jest zwrócenie uwagi na kwestię kresu istnienia zabytków architektury, a zatem określenia granicy, po przekroczeniu której interwencje konserwatorskie tracą sens.

Kontynuuję w nim wątki, które poruszałem w ubiegłych latach ${ }^{1}$. Ponowne ich podejmowanie uważam za celowe zarówno z powodu sytuacji, w jakiej zabytki architektury w Polsce znajdują się od dekad, jak też z powodu nowych okoliczności, stawiających możliwości ich ochrony pod znakiem zapytania. Przykłady, które omawiam szerzej, zaczerpnąłem ze swojej praktyki zawodowej. Rezygnuję z zamieszczenia materiału ilustrującego niniejszy tekst, ponieważ materiały fotograficzne zamieszczone na licznych stronach internetowych dostarczają wystarczająco obszernej informacji wizualnej na temat omawianych problemów.

\section{Stan rzeczy}

Jak wszystkie rzeczy materialne, tak i wszystkie istniejące oraz przyszłe budowle czeka zakończenie ich egzystencji. Piramidy Starego Państwa, których boi się czas, czy mury Sacsayhuamán są tu pomijalnymi wyjątkami. Tragedia paryskiej Notre Dame w 2019 pokazała, jak wrażliwe i bliskie końca potrafią być nawet te najwybitniejsze, i z pozoru najlepiej chronione, pomniki architektury...

Interwencje konserwatorskie mogą i powinny wprawdzie spowalniać procesy niszczenia, ale nie są w stanie ich powstrzymać. Przyczyny „śmierci” budynków - podobnie jak śmierci istot żywych - są zróżnicowane.

Można mówić o „śmierci naturalnej”, dotykającej budynki w wyniku fizycznego starzenia się i fizycznego zużycia, przyspieszanych przez procesy nieodwracalnej, technicznej i funkcjonalnej degradacji, powodowanej jednak raczej czynnikami społeczno-ekonomicznymi niż czysto technicznymi. Wyrazistym przykładem są losy architektury drewnianej, która w drugiej połowie XX wieku zniknęła niemal całkowicie z krajobrazu kulturowego Polski, nieodwracalnie go zmieniając. Proces ten był naturalny i nieunikniony, zarówno wobec zmian cywilizacyjnych, jak i ubóstwa czy wręcz prymitywizmu technicznego większości tego budownictwa, którego skończoność - alei łatwa odtwarzalność - były cechami wręcz biologicznymi. W przeciwieństwie jednak do opuszczonych, czasem częściowo zrujnowanych, sprzedawanych za „1 euro" murowanych domów włoskich miasteczek czy chłopskich domów Dolnej Austrii, polskie wiejskie "chałupy” były w zasadzie nieadaptowalne do współczesnych potrzeb z powodów technicznych, a z historycznych nieakceptowane przez potomków chłopów, stanowiących większość ludności współczesnej Polski. Z nieco innych powodów zakończyła egzystencję większość domów podcieniowych, stanowiących charakterystyczny element historycznego

${ }^{1}$ Bukal, G., Produkcja zabytków jako problem konserwatorski (przykład Gdańska), [w:] Szmygin, B. (red.), Wspólczesne problemy teorii konserwatorskiej w Polsce, Warszawa: PKN ICOMOS, 2008, ss. 1724; Bukal, G., Ochrona i zagrożenie wartości zabytków - czyli o skutkach braku wartościowania $i$ co dalej... [w:] Szmygin, B. (red.), Wartościowanie zabytków architektury, Warszawa: PKN ICOMOS, 2013, ss. 61-70. 
krajobrazu kulturowego Delty Wisły. Domy te, których najwybitniejsze pod względem wartości, znane przykłady powstały stosunkowo późno, bo mniej więcej w okresie stulecia od pierwszych dekad XVIII wieku, a których dokładnej liczby nie znamy, zachowały się jako grupa zabytków szczątkowo ${ }^{2}$. W przeciwieństwie do ubogich domów Mazowsza czy Kujaw były one dużymi, starannie wznoszonymi i wykończonymi konstrukcjami, mogącymi po niewielkich adaptacjach spełniać współczesne standardy. Pod względem technicznym mogłyby potencjalnie istnieć przez następne kilkaset lat, jak dowodzi tego stan kilku zachowanych obiektów w Trutnowach, Miłocinie czy Mikoszewie. Obiekty te uległy jednak po 1945 roku „procesom historycznym”. Te, które ocalały, opuszczone przez właścicieli, zasiedlane były przez napływającą do Prus ludność polską, próbującą odtwarzać swoją egzystencję w warunkach powojennej traumy, chaosu i lat niewydolnego ekonomicznie systemu realnego socjalizmu. Zaniedbywane i deformowane przez prymitywne remonty i adaptacje, a niekiedy przypadkowo lub rozmyślnie dewastowane, czasem uwikłane w nierozwiązywalne łamigłówki prawno-własnościowe oczekują na swój naturalny koniec. Przykładów podobnych sytuacji różnych grup zabytków jest w Polsce wiele.

Przypadki „śmierci gwałtownej” budynków powodowanej przez zdarzenia losowe (np. pożary) istniały i będą zdarzać się zawsze.

Szczególnie interesujące są popełniane na zabytkach „morderstwa z premedytacją. Zjawisko to zaistniało w Polsce po zmianach ustrojowych, a polega na doprowadzaniu budynku - przez jego właściciela - do stanu śmierci technicznej poprzez celowe zaniedbania lub niszczenie. Występuje w sytuacji „presji inwestycyjnej”, kiedy korzyści ekonomiczne spodziewane w wyniku „uwolnienia” działki od zabytku spowoduje wzrost jej atrakcyjności ekonomicznej³.

Pomijając sytuacje szczególne, w których $\mathrm{z}$ jakichś powodów zabytek w stanie technicznym umożliwiającym dalszą egzystencję musiał zostać rozebrany, wymienione kategorie przyczyn śmierci zabytków sprowadzają się jednak do wspólnego mianownika. Jest nim nieodwracalne pogorszenie stanu technicznego, prowadzące do „śmierci technicznej” budynku, czyli sytuacji, w której - obiektywnie z technicznego punktu widzenia - stan jego substancji materialnej jest tak zły, że żadne zabiegi nie mogłyby przywrócić mu możliwości użytkowania; budynek mógłby pozostawać co najwyżej w stanie ruiny czy reliktów. (Odrzucając ewentualność całkowitej wymiany substancji poprzez „odtworzenie” obiektu, albowiem nie tylko nie zapobiega ono utracie zabytku, ale ją potwierdza...)

2 W rejestrze zabytków figurują 43 obiekty; Zybała, T., Personal communication, August 10, 2021).

Zob. np. https://sip.lex.pl/orzeczenia-i-pisma-urzedowe/orzeczenia-sadow/ii-osk-896-16-skreslenie-z-rejestruzabytkow-wyrok-522558022. 


\section{Perspektywy przetrwania}

Zgodnie z zapisami obowiązującej Ustawy ${ }^{4}$ Ochronie i opiece podlegają, bez względu na stan zachowania: 1) zabytki nieruchome będące (...): krajobrazami kulturowymi, układami urbanistycznymi, ruralistycznymi i zespołami budowlanymi, dziełami architektury i budownictwa, dziełami budownictwa obronnego etc. etc. Deklaratywny język ustawy nie zmienia faktu, że warunkami koniecznymi do zachowania zabytków architektury są:

- rzeczywiste zainteresowanie ich właścicieli czy gestorów, czy też bardziej ogólnie zainteresowanie społeczne, to znaczy społeczeństw czy społeczności, które w różny sposób mogą wpływać na postawy właścicieli poprzez tworzenie regulacji prawnych, wspierając ich lub też wywierając na nich presję (z pomocą obowiązującego prawa);

- możliwości ekonomiczne właścicieli (gestorów), pozwalające - lub nie - na realizację właściwych interwencji;

- obiektywne uwarunkowania techniczne. Dotyczą one zarówno stanu technicznego obiektu zabytkowego, jak też lokalnych lub ponadlokalnych możliwości realizacji zadań technicznych. W obu przypadkach możliwości ekonomiczne właściciela (inwestora) mogą okazywać się niewystarczające z powodu beznadziejnego stanu obiektu lub braku pozyskania dostatecznie wykwalifikowanej kadry technicznej, będącej w stanie zadania techniczne realizować.

W większości przypadków czynniki te występują zawsze i są współzależne, a elementem koniecznym do uwzględnienia jest tu wynik rachunku ekonomicznego, czyli racjonalność działań inwestycyjnych, dotycząca zarówno ekonomicznego, jak i technicznego aspektu każdego przedsięwzięcia.

Jako przykład posłużyć może duży pałac w Głębowicach (gmina Wińsko, powiat wołowski, województwo dolnośląskie). Zbudowany między 1802 a 1826 rokiem, prawdopodobnie na reliktach starszego budynku, był po 1945 roku dewastowany i zaniedbywany; w 1988 roku zawaliła się partia frontowa korpusu; we wstępnej ekspertyzie z 1996 roku stopień „destrukcji technicznej” zabytku określono już na 60-70\%5. Inwestor, który nabył pałac, zamierzał odbudować go i adaptować na ośrodek wypoczynkowy. Po przeprowadzeniu dokładniejszych badań stanu technicznego w 1996 roku ujawniono między innymi skutki wady pierwotnej obiektu, jaką jest jego lokalizacja; zbudowano go na podmokłym terenie, w odległości kilkunastu metrów od brzegu dużego stawu, przy czym poziom posadzki piwnic usytuowano ok. $15 \mathrm{~cm}$ poniżej lustra wody. Pozbawione na etapie budowy izolacji ściany piwnic ${ }^{6}$ były w ciągu lat istnienia budynku stale i silnie zawilgacane, czyniąc przyszłe użytkowanie tej kondygnacji niemożliwym bez wykonania skomplikowanych prac zabezpieczających i izolacyjnych. Pod względem technicznym byłyby one zapewne wykonalne i efektywne (izolacje pionowe i poziome z koniecznością przecinania

\footnotetext{
${ }^{4}$ Ustawa z dnia 23 lipca 2003 r. o ochronie zabytków i opiece nad zabytkami Dz. U. z 2021 r. poz. 710, 954, Art. 6. 1.

Przyłęcki, M., Ekspertyza zabytkowego pałacu w Głębowicach w woj. wrocławskim, Wrocław, 1996, s. 10;

${ }^{6}$ Ściany o grubości ok. $110 \mathrm{~cm}$ zbudowano z otoczaków granitowych i cegły na słabej zaprawie wapiennej.
} 
murów, osuszanie, wymiana skorodowanej cegły, ściany szczelne itp.), ale przewidywane koszty tylko tych robót zniechęciły inwestora do realizacji przedsięwzięcia, którego elementami miały być oprócz odbudowy i adaptacji pałacu także rewaloryzacja otaczającego go dużego założenia parkowego oraz restauracja znajdujących się w nim kaplicy i oranżerii. Ponadto obiekt znajduje się na uboczu głównych szlaków turystycznych, w sąsiedztwie bardzo małej wsi, toteż stopień zainteresowania nim i spodziewane efekty ekonomiczne zostały ocenione przez inwestora jako niewspółmiernie niskie wobec koniecznych nakładów. Rezultatem obecnej sytuacji jest ginący „zabytek-zombie”, czyli rozpadająca się w sposób naturalny, porastająca dziką roślinnością, pozbawiona większości dachów ruina. Bardzo podobne przykłady można mnożyć, i nie tylko w Polsce. Nawet w przypadkach występowania zainteresowania społecznego i potencjalnie większej niż w przypadku Głębowic atrakcyjności miejsca jedynym wyjściem jest pogodzenie się z utratą takiego zabytku lub zachowanie go w stanie możliwie zagospodarowanej ruiny, jak stało się to ze zniszczonym w 1945 roku i zburzonym częściowo w latach 70. XX wieku pałacem w nieodległym od Głębowic Żmigrodzie.

$\mathrm{Na}$ stopień rzeczywistego zainteresowania zabytkami, skutkującego podejmowaniem przez zamieszkujące w ich otoczeniu społeczności konkretnych działań, nie ma wpływu nikt. Może się ono pojawiaćlub nie. Zwyklema jednak charakter pobieżnych, „popkulturowych” fascynacji, wyrażających się na przykład w opisywaniu na licznych blogach i portalach internetowych różnych „miejsc opuszczonych". Czasem wszakże przenosi się to na zainteresowanie lokalnych władz samorządowych, które pragmatycznie upatrując w tym konkretnych korzyści płynących z rozwoju turystyki, zaczynają podejmować wysiłki zmierzające do poprawy kondycji takiego czy innego zabytku; przykładem może być zespół forteczny w Srebrnej Górze. Wiele obiektów istnieje jednak poza sferą społecznych zainteresowań. Są to pozbawione pierwotnych czy wtórnych funkcji, położone w nieatrakcyjnej lokalizacji rezydencje, zabytki architektury przemysłowej, obronnej czy obiekty sakralne pozbawione wiernych, jak choćby drewniane cerkwie, kościoły protestanckie czy synagogi.

Możliwości ekonomiczne potencjalnie zainteresowanych są pochodną ich efektywności ekonomicznej lub organizacyjnej, jak bywa to w przypadkach pozyskiwania funduszy ze źródeł publicznych lub UE. To drugie dotyczy raczej samorządów niż inwestorów prywatnych (odnosi się to prawdopodobnie do wpływu inwestorów spoza Polski). Potencjał ekonomiczny społeczeństwa polskiego jest ciągle zbyt słaby, aby znaczący procent jego indywidualnych członków miał poprzez swoje możliwości inwestycyjne wpływ na znaczącą poprawę stanu zasobu zabytkowego.

Ostatecznie jednak zachowanie - lub nie - każdego budynku zależy od jego indywidualnej odporności na zniszczenie, czyli zdolności do przetrwania okresu zaniedbania przed osiągnięciem stanu śmierci technicznej. Czasem sytuacja taka może trwać wiele dziesięcioleci, ale w polskich warunkach okres ten jest już bardzo długi. Dla wielu zabytków rozpoczął się w po roku 1989, ale dla wielu przed rokiem 1945 lub wcześniej.

Przyjmując takie założenia, można próbować określać, jakie grupy zaniedbanych zabytków mają możliwości dalszej egzystencji, a jakie prawdopodobnie będą z krajobrazu Polski znikały. Możliwości rewaloryzacji zespołów czy rehabilitacji poszczególnych obiektów zależą oczywiście 


\section{Grzegorz Bukal}

od wielu czynników, toteż trudno odnosić się do losów i perspektyw indywidualnych obiektów. Diagnoza i prognozy na ten temat zawiera wprawdzie raport NID z roku $2017^{7}$, ale przedstawiam tu własne opinie, które zresztą częściowo się z tym dokumentem pokrywają.

Najbardziej zagrożone są niewątpliwie obiekty w bardzo złym stanie technicznym, z różnych powodów nieatrakcyjne pod względem inwestycyjnym (użytkowym). Stanu technicznego nie należy utożsamiać ze stanem integralności danego obiektu; czynnikiem decydującym o jego przetrwaniu jest solidność konstrukcji i zdolność do opierania się naturalnym procesom niszczenia. Dowodzi tego trwanie przez stulecia wielu zaniedbanych ruin zamków. Podobnie ma się rzecz z murowanymi kościołami, rezydencjami, fortyfikacjami, budynkami przemysłowymi czy budowlami inżynieryjnymi. Nawet pozbawione drewnianych konstrukcji dachowych, stropów czy sklepień są zdolne do trwania w formie ruin i - co równie ważne - na ogół możliwe do skutecznego zabezpieczenia. Możliwa jest też konsolidacja ich struktur, a nawet reintegracja i doprowadzenie do użytkowania.

Różne nienadające się do adaptacji obiekty, takie jak niektóre budowle forteczne lub inżynieryjne, mogą trwać nawet jako ruiny lub relikty, zmieniając wprawdzie nieodwracalnie swój charakter, ale i nie znikając całkowicie z krajobrazu w przypadku kontrolowanej „renaturyzacji” i przy stosowaniu tylko koniecznych zabezpieczeń, pozwalających na odsuwanie kresu ich istnienia.

Istnieją jednakże obiekty, których konstrukcja i substancja została zniszczona lub zdegradowana $\mathrm{w}$ takim stopniu - i to nawet przy zachowaniu pełnej integralności ich struktury - że podejmowanie wobec nich działań budowlano-konserwatorskich trudno byłoby uzasadnić. Zaliczyć należy do tej kategorii także budynki w praktyce nieadaptowalne ze względów funkcjonalnych, ekonomicznych czy społecznych.

Liczną ich grupę stanowią murowane, czynszowe kamienice wznoszone w ostatnich dekadach wieku XIX i pierwszych dekadach XX, w okresie II rewolucji przemysłowej; zarówno w historycznych centrach, jak i na przedmieściach miast. Te wznoszone dla niezamożnych najemców nie są i nie miały być znaczącymi dziełami architektury. Ich wystrój ogranicza się do wzornikowych elementów fasad, a pod względem użytkowym charakterystyczne były dla nich - zależnie od miejsca i czasu powstania - „podwórka studnie”, labirynty oficyn, sutereny, pokoje berlińskie, wspólne sanitariaty na piętrach lub podwórkach itp. Wszystko to, z czym usiłowali walczyć reformatorzy miast i architekci moderniści. Budynki te, przed rokiem 1914 jeszcze nowe, w 1939 były jeszcze dość nowe i nie wymagały poważnych remontów, lub też nie były remontowane przez właścicieli z powodów ekonomicznych. Komunalizowane po 1945 i nadal z różnych powodów nieremontowane, i zdegradowane często do stanu „półruin”, trwają do dziś; czasem się zawalają. Oszczędzona podczas obu wojen światowych Łódź jest wyrazistą ilustracją tego przypadku ze względu na wielkość zespołu, choć podobne zabytki znaleźć można w wielu większych i mniejszych miastach Polski.

Brudnicki, J., Dawidowicz, M., Jagielska, E., Jankowski, D., Kłoczko, A., Kozioł, A., Legutko-Kobus, P., Lorek, A., Misiuk, Z., Popławska-Bukało, E., Skaldowski, B., Warchoł, M. Raport o stanie zachowania zabytków nieruchomych w Polsce. Zabytki wpisane do rejestru zabytków (księgi rejestru A i C). Narodowy Instytut Dziedzictwa, 2017 , https://nid.pl/pl/Wydawnictwa/ inne\%20wydawnictwa/RAPORT\%200\%20STANIE\%20ZACHOWANIA\%20ZABYTK\%C3\%93W\%20NIERUCHOMYCH. pdf. 
Podobny losczeka zapewnezczasem znaczny procent, jeśli niewiększość, architektury przemysłowej czy powiązanej z infrastrukturą kolejową z tego okresu, niezależnie od potencjalnych, technicznych zdolności tych obiektów do dalszego trwania. W przeciwieństwie do budynków mieszkalnych głównym powodem jest tu praktyczna niezdolność do adaptacji, jak np. w przypadku kolejowych wież ciśnień, i nieopłacalność takich przedsięwzięć. Nie można też poważnie, z punktu widzenia prawidłowości postępowań architektoniczno-konserwatorskich, traktować „radykalnych” adaptacji budynków przemysłowych na galerie handlowe czy „lofty”. Zabytki są w tych przypadkach tylko komercyjnie traktowanym sztafażem, przedmiotem, a nie podmiotem działań.

Zachowywanie takich obiektów (poza wyjątkami) w charakterze utrwalonych ruin, zwłaszcza w krajobrazie miejskim, nie jest $\mathrm{z}$ różnych względów możliwe i uzasadnione.

Przyczyną naturalnych śmierci budynków drewnianych, pochodzących z przełomu XIX i początków XX wieku jest ich naturalne zużycie. Zabytki starsze, jako już bardzo rzadkie, wydają się, paradoksalnie, mniej zagrożone. Zarówno ze względu na staranniejszą ochronę - nawet jeśli przyjmowała ona formę transferów do parków etnograficznych - jak i kontynuację funkcjonowania, jak to ma miejsce w przypadku drewnianych kościołów, ale także rodzaj konstrukcji - np. z użyciem drewna lepszej jakości czy o znacząco większych przekrojach. Pospolite, wznoszone w dziesiątkach tysięcy budynki mieszkalne, gospodarcze czy przemysłowe traktowano czysto użytkowo, czasem wznoszono je przy założeniu ich tymczasowości, z perspektywą wymiany, co zresztą następowało. Przykładem mogą być budynki w podmiejskich letniskach (np. podwarszawski „świdermajer”), czy niewykorzystywane od dziesięcioleci wiatraki. Wiele takich obiektów zachowało się zatem, niejako mimochodem, skutkiem przemian historycznych.

Nie należy także żywić iluzji wobec możliwości zachowania elementów wystroju i detalu architektonicznego zabytków nawet relatywnie bezpiecznych pod względem struktury i konstrukcji, ale znajdujących się od lat w stanie głębokiego zaniedbania. Dotyczy to głównie obiektów rezydencjonalnych, opuszczonych i wywłaszczonych po 1945, a po 1989 często opuszczonych ponownie w nowych warunkach ekonomicznych. Dobrym przykładem jest tu los dolnośląskich czy pruskich pałaców z XVIII czy XIX wieku. Perspektywa możliwości restauracji i zachowania setek (?) polichromowanych stropów, drewnianych posadzek czy barokowych sztukaterii, poddawanych przez prawie osiemdziesiąt lat działaniu wody, zmian temperatury i dewastacji rysuje się niestety wyraźnie i ponuro.

Paradoksalnie w podobnej sytuacji są wnętrza nominowanych do rangi zabytków powojennych budynków (soc-)modernistycznych. Tempo estetyczneji technicznej degradacji tych obiektów było rezultatem procesu, postępującego już od wymuszanego prymitywizowania projektów (w wyniku ich typizacji, projektowania ubogiej infrastruktury technicznej i wykończenia), następnie deformowania w trakcie realizacji, aż po niedbałą eksploatację wskutek braku środków na remonty i przy braku rzeczywistych właścicieli. Moda na estetykę modernizmu nie dostarcza odpowiedzi na pytania o metody prawidłowego, konserwatorskiego podejścia do budowlanej tandety wypaczonych „od nowości” okien, płytek PCV, lamperii olejnych czy topornej, zużytej armatury sanitarnej, w kontekście zachowania ich autentyzmu. Warto zresztą zwrócić uwagę, że niska jakość techniczna była cechą nie tylko polskiej architektury „socmodernistycznej”; występowała również w Europie Zachodniej. Była pochodną zarówno tendencji do redukcji kosztów, umasowienia 


\section{Grzegorz Bukal}

i uprzemysłowienia produkcji, jak i projektowania niesprawdzonych w konkretnych warunkach rozwiązań technicznych, takich jak płaskie dachy, powłoki żelbetowe, duże powierzchnie przeszklone itp., przy ówczesnym braku odpowiednich technologii i materiałów do ich realizacji. Efekty tego dotknęły nawet takich, rzeczywiście już zabytkowych, ikon modernizmu jak choćby Villa Savoye.

\section{W liczbie siła, czyli: „Polacy, nic się nie stało...” (?)}

Oparcie systemu ochrony zabytków na holistycznie (i globalistycznie) sformułowaną koncepcję dziedzictwa ${ }^{8}$ doprowadziło do sytuacji, w której przedmiotem ochrony może być właściwie wszystko to, co $\mathrm{w}$ środowisku zarówno kulturowym, jak i naturalnym planety istnieje, i istnieć będzie; zarówno w sensie materialnym, jak i nie. Wadą tego idealistycznego stanowiska jest latwość sprowadzenia go do absurdu, jak też wykorzystywanie do osiągania aktualnych celów politycznych czy ekonomicznych, ponieważ cała sfera ochrony dziedzictwa opiera się w istocie przede wszystkim na emocjach, zarówno indywidualnych, jak i zbiorowych. Racjonalna realizacja koncepcji dziedzictwa na poziomie praktyki konserwatorskiej wymaga natomiast umiejętności oceny wartości obiektów, ich kategoryzacji i klasyfikacji oraz odpowiedniego doboru metod i narzędzi ochrony. Próby ochrony zabytków bez stosowania tych narzędzi są nieskuteczne.

Według danych Narodowego Instytutu Dziedzictwa ${ }^{9}$ liczba zabytków nieruchomych, wpisanych do rejestru zabytków w Polsce (bez archeologicznych) wynosi 78 343; jest ich od 1941 w województwie świętokrzyskim do 8912 w małopolskim, średnio daje to 4608 obiektów na jedno województwo. Należy zwrócić uwagę, że liczba ta jest aż o ponad 10\% większa od analogicznej ich liczby w roku 2016, wynoszącej 70700 obiektów, choć brak precyzyjnych statystyk na ten temat. Łączna liczba istniejących 135 pomników historii oraz obiektów z listy WHL UNESCO ${ }^{10}$ jest przy niej pomijalna. Do zbioru zabytków rejestrowych dodać jednak należy zbiór zabytków ewidencjonowanych, wynoszący w roku 2016183000 obiektów. Nie podejmując się określić ich obecnej liczby w skali kraju, przytoczę tylko ich liczbę na obszarze gminy Gdańsk - z wyłączeniem obiektów i obszarów z terenu d. Stoczni Gdańskiej... - wynosi ona 7267 obiektów.

Biorąc zatem pod uwagę stan administracji ochrony zabytków w Polsce, nie sposób nie zadać pytania o rzeczywiste możliwości prawidłowej zarówno pod względem organizacyjnym, jak i doktrynalnym „obsługi” przez nie tak ogromnego zasobu. Formułując to bardziej jednoznacznie, należałoby się poważnie zastanowić, czy i w jaki sposób wojewódzkie urzędy ochrony zabytków, dysponujące kilkudziesięcioma pracownikami - nawet przy założeniu ich wystarczających kompetencji zawodowych w odniesieniu do całej problematyki architektoniczno-konserwatorskiej, a nie jest to oczywiste - są w stanie skutecznie kontrolować stan zabytków liczący średnio

\footnotetext{
8 Zob. Convention Concerning the Protection of the World Cultural and Natural Heritage, https://whc.unesco.org/en/ conventiontext.

9 https://mapy.zabytek.gov.pl/nid/.

${ }^{10} \mathrm{https} / /$ nid.pl/pl/Informacje_ogolne/Zabytki_w_Polsce/Pomniki_historii/;

https://nid.pl/pl/Informacje_ogolne/Zabytki_w_Polsce/Miejsca_na_liscie/Lista informacyjna.
} 
tysiące obiektów. Zwłaszcza że tworzenie ewidencji zabytków jest działaniem ciągłym - obszar zainteresowań konserwatorskich rozszerza się, a liczba obiektów uznanych za zabytkowe zwiększa się regularnie ${ }^{11}$. Gdyby jeszcze rzeczywiście podstawowym celem ewidencji było rozpoznanie zasobu zabytkowego poprzez badania historyczne i terenowe oraz jego udokumentowanie, służące poznaniu i utrwaleniu wiedzy o dziedzictwie kulturowym, czyli gdyby ewidencja była tym, czym być powinna, zjawisko, które nazywam „produkcją zabytków”, mogłoby zostać ograniczone. Jednakże, z niejasnych powodów ewidencja od 2011 roku stała się również jedną z niewymienionych literalnie w ustawie form ochrony zabytków ${ }^{12}$, czyli rodzajem „wicerejestru”, a znajdujące się w niej obiekty „wicezabytkami”, które administracja ochrony zabytków traktuje podobnie jak zabytki rejestrowe, czego uciążliwych skutków doświadczają zarówno ich gestorzy czy inwestorzy, zmuszeni w ramach różnych prac do uzgadniania ich przez urzędy ochrony zabytków, jak i one same, zasypane mnogością spraw.

Bezrefleksyjna wiara w paradygmat wszechogarniającego dziedzictwa i jego stale powiększającego się zasobu nie powoduje wzrostu jakości tegoż (nieco analogicznie jak w przypadku prawa Kopernika-Greshama), bo dziedzictwem są czy będą zarówno bloki z lat 60 . XX wieku, hale hipermarketów, jak i budowany „zamek” w Stobnicy czy nieistniejąca jeszcze replika Pałacu Saskiego (choć właściwie - „ruskiego”, a to z powodu okoliczności jego powstania...). Powoduje także marnowanie funduszy publicznych, przeznaczonych na ustawowe dofinansowywanie interwencji, bo żadne środki finansowe, jak też wzmocnienie kadr urzędów ochrony nigdy nie będą w tej sytuacji wystarczające.

\section{Rejestracja - i co dalej...}

Kwestię stanu technicznego zabytku, decydującego o możliwości jego zachowania, obowiązująca Ustawa traktuje niejasno, z jednej strony obejmując je ochroną bez względu na stan zachowania, $\mathrm{z}$ drugiej jednak strony pozwalając na skreślenie z rejestru zabytku, który uległ zniszczeniu w stopniu powodującym utratę jego wartości historycznej, artystycznej lub naukowej ${ }^{13}$. Skrajną konsekwencją takiego sposobu myślenia byłaby możliwość wpisania obiektu do rejestru, a wkrótce potem... wnioskowanie o jego skreślenie z powodu utraty wartości.

Ilustracją takiej właśnie sytuacji jest los części nieistniejącego już zespołu hal na terenach byłej Stoczni Gdańskiej (szczegóły identyfikujące obiekt nie mają żadnego znaczenia dla istoty tego przypadku). Wzniesiony w latach 1927(-29)-1942, na miejscu zabudowy z początku XX wieku, kompleks został rozebrany po roku 1977 i ostatecznie po roku 1985 zachowała się tylko połowa ścian zewnętrznych jednej z dużych hal oraz jej przybudówka, stanowiące razem ok. 10\% powierzchni zespołu. W wyniku rozbiórki po 1977 zachowaną połowę hali przykryto nowym, stalowym dachem. Przed rokiem 2020 właściciel obiektu uzyskał pozwolenie na jego rozbiórkę, z którego nieprzewidująco, ze względów

\footnotetext{
${ }^{11}$ https://www.nid.pl/pl/Informacje_ogolne/Zabytki_w_Polsce/Ewidencja_zabytkow.

${ }^{12}$ Ibidem.

${ }_{13}$ Art. 13. 1 Ustawy z dnia 23 lipca 2003 r. o ochronie zabytków i opiece nad zabytkami, Dz. U. z 2021 r. poz. 710, 954.
} 
użytkowych, nie skorzystał. W styczniu 2020, w związku z zamiarem umieszczenia terenów postoczniowych na Liście Dziedzictwa Światowego obiekt został jednak, wraz z grupą innych, wpisany do rejestru zabytkó $\mathrm{w}^{14} \mathrm{z}$ jednozdaniowym uzasadnieniem, stwierdzającym posiadanie wartości ustawowych, mimo iż wartości takich nigdy nie wykazywał i nie wykazuje; nie reprezentuje też żadnych wartości niematerialnych, które uzasadniałyby zachowanie go w formie pamiątki („relikwii”). Potwierdziła to nawet wykonana na zlecenie NID w roku 2019 ekspertyza ${ }^{15}$, oceniająca jego wartość na 120 z możliwych 600 punktów.

Abstrahując tu od wartości ustawowych czy dominującej, politycznej motywacji przedmiotu wpisu, należy zwrócić uwagę właśnie na stan zachowania obiektu ${ }^{16}$. W wyniku naturalnych wieloletnich procesów, zachodzących w pozbawionych skutecznej izolacji pionowej ścianach budynków posadowionych nisko ponad lustrem wody, znaczne, dolne partie elementów stalowych oraz ścian ceglanych uległy głębokiej korozji. Opisywanemu obiektowi nie można ani przywrócić stanu oryginalnej integralności (np. z roku 1930, 1942, 1957 czy 1985?), ani konserwować go w obecnej formie w postaci technicznego „rezerwatu”, ponieważ nie zachował ciągłości funkcji ani historycznego wyposażenia, jak też został nieodwracanie zdezintegrowany i technicznie zużyty, a obecny sposób funkcjonowania z przyczyn oczywistych może trwać tylko czasowo i nie wiadomo, jak długo jego dalsze użytkowanie będzie w ogóle możliwe i bezpieczne.

\section{Konkluzje}

Architektura jest wprawdzie sztuką użytkową, ale większość obiektów budowlanych - zarówno zabytkowych, jak i współczesnych - nie powstała jako dzieła sztuki. Nie są to bowiem obiekty wytworzone wyłącznie lub przede wszystkim $\mathrm{w}$ wyniku potrzeb emocjonalnych ich twórców i w celu oddziaływania na emocje odbiorców w sferze doznań estetycznych. Racją bytu większości architektury była i jest możliwość realizacji zadań technicznych w sposób ściśle odpowiadający założeniom użytkowników. Utylitaryzm podporządkowywał ją regułom techniki i ekonomii pod względem przyjętych rozwiązań funkcjonalno-przestrzennych, formalnych i materiałowotechnicznych. Warunkował cykl życiowy obiektów, obejmujący - w przypadku pewnych kategorii obiektów, jak np. przemysłowe, czy militarne - także brutalne, czasem estetycznie degradujące przekształcenia, aż do planowanej śmierci technicznej. Jak też to, że koniec egzystencji obiektu użytkowego, jest tak naturalny, jak dążenie do „wiecznego", w stanie oryginalnym, zachowania klasycznie rozumianego dzieła sztuki. I koniec taki powinien być postrzegany jako naturalny, a w pewnych okolicznościach akceptowalny, nawet $\mathrm{z}$ konserwatorskiego punktu widzenia.

${ }^{14}$ Decyzja Pomorskiego Wojewódzkiego Konserwatora Zabytków w sprawie wpisania do rejestru zabytków z dn. 07.01.2020, PWKZ. 5140.5.2017. (AK) PŚ, s. 10.

${ }^{15}$ Orchowska-Smolińska, A., Woźniakowski, A., Ekspertyza okréslająca dopuszczalny zakres ingerencji inwestycyjnej na terenie zespołu zabytkowego dawnej Stoczni Gdańskiej w Gdańsku w kontekśsie zachowania krajobrazu kulturowego oraz ochrony wartości dziedzictwa materialnego i niematerialnego tego obszaru, miejsca proponowanego do wpisu na Listę Światowego Dziedzictwa, Gdańsk, 2019.

${ }^{16}$ Wzniesiono go w konstrukcji szkieletu stalowego (profile 2T/140 - słupki i rygle), stanowiącego usztywnienie dla cienkich $(12 \mathrm{~cm})$ ścian z cegły. 
Podstawą decyzji konserwatorskich w odniesieniu do obiektów budowlanych powinno być krytyczne i realistyczne wartościowanie oparte na zrozumiałym, funkcjonalnym systemie ${ }^{17}$, a jego efektem - możliwe nawet w świetle obowiązujących zapisów ustawowych - różnicowanie wymagań wobec zasad ochrony i postępowania w zależności od wartości i kategorii obiektu. W tym zakresie leżą decyzje o celowości i racjonalności podejmowania działań budowlano-konserwatorskich. Wyposażeni w niebezpieczne (ale tylko wobec podmiotów słabych!) narzędzie, jakim jest „władza dyskrecjonalna”, konserwatorzy powinni rozumieć hierarchię ważności problemów, nie wymagać niemożliwego i nie prezentować postawy przede wszystkim filoestetycznej, której źródeł należy upatrywać w humanistyczno-konserwatorskim profilu wykształcenia większości kadr urzędów ochrony i zarządzania zasobem zabytkowym. Prowadzi to do tego, że ważne decyzje dotyczące konserwacji zabytków architektury podejmują zwykle ludzie bez wystarczających kwalifikacji zawodowych w zakresie architektury czy budownictwa.

Tłem tej kwestii jest koncepcja dziedzictwa i rozumienie jej konsekwencji.

Problemem powiązanym, wynikającym ze stopnia rozwoju współczesnej polskiej państwowości, jest upolitycznienie mechanizmów decyzyjnych, a zatem podległość i uległość służb ochrony zabytków wobec ich mocodawców.

\footnotetext{
${ }^{17}$ Nie rozwijam szerzej tego ważnego wątku, ponieważ nie jest on głównym przedmiotem niniejszego tomu. Problem wartościowania zabytków jest stale obecny w polskiej literaturze; zob. np. Wartościowanie zabytków architektury, Szmygin, B. (red.). Warszawa: PKN ICOMOS, 2013 - wyrazilem tam swoje zasadnicze poglądy i sugestie na ten temat; Bukal, G., Ochrona i zagrożenie wartości zabytków - czyli o skutkach braku wartościowania i co dalej... [w:] B. Szmygin (red.), Wartościowanie zabytków architektury, Warszawa: PKN ICOMOS, 2013, ss. 68-70. Propozycje systemu oceny zabytków przedstawili ostatnio: Szmygin, B., Fortuna-Marek, A. \& Siwek, A., Wartościowanie dziedzictwa w systemie SV - metoda i przykłady zastosowania, Lublin: Politechnika Lubelska, 2017.
} 


\section{Grzegorz Bukal}

\section{Bibliografia}

Brudnicki, J., Dawidowicz, M., Jagielska, E., Jankowski, D., Kłoczko, A., Kozioł, A., Legutko-Kobus, P., Lorek, A., Misiuk, Z., Popławska-Bukało, E., Skaldowski, B., Warchoł, M., Raport o stanie zachowania zabytków nieruchomych $w$ Polsce. Zabytki wpisane do rejestru zabytków (księgi rejestru A i C). Narodowy Instytut Dziedzictwa, 2017.

Bukal, G., Produkcja zabytków jako problem konserwatorski (przykład Gdańska), [w:] B. Szmygin (red.), Wspótczesne problemy teorii konserwatorskiej w Polsce, Warszawa: PKN ICOMOS, 2008, ss.17-24.

Bukal, G., Ochrona i zagrożenie wartości zabytków - czyli o skutkach braku wartościowania i co dalej... W: B. Szmygin (red.), Wartościowanie zabytków architektury, Warszawa: PKN ICOMOS, 2013, ss.61-70.

Convention Concerning the Protection of the World Cultural and Natural Heritage, https://whc. unesco.org/en/conventiontext

Decyzja Pomorskiego Wojewódzkiego Konserwatora Zabytków w sprawie wpisania do rejestru zabytków z dn. 07.01.2020, PWKZ. 5140.5.2017. (AK) PŚ, s. 10.

https://download.cloudgdansk.pl/gdansk-pl/d/202105169409 /postanowieniepomorskiego-wojewodzkiego-konserwatora-zabytkow-z-dnia-21-12-2020r-skan.pdf

https://sip.lex.pl/orzeczenia-i-pisma-urzedowe/orzeczenia-sadow/ii-osk-896-16skreslenie-z-rejestru-zabytkow-wyrok-522558022

https://www.nid.pl/pl/Informacje_ogolne/Zabytki_w_Polsce/Ewidencja_zabytkow https://mapy.zabytek.gov.pl/nid/

https://nid.pl/pl/Informacje_ogolne/Zabytki_w_Polsce/Pomniki_historii/;

https://nid.pl/pl/Informacje_ogolne/Zabytki_w_Polsce/Miejsca_na_liscie/Lista informacyjna

Brudnicki, J., Dawidowicz, M., Jagielska, E., Jankowski, D., Kłoczko, A., Kozioł, A., LegutkoKobus, P., Lorek, A., Misiuk, Z., Popławska-Bukało, E., Skaldowski, B., Warchoł, M, Raport o stanie zachowania zabytków nieruchomych $w$ Polsce. Zabytki wpisane do rejestru zabytków (księgi rejestru A i C). Narodowy Instytut Dziedzictwa, 2017.

https://nid.pl/pl/Wydawnictwa/inne\%20wydawnictwa/RAPORT \%20O \%20 STANIE\%20 ZACHOWANIA\%20ZABYTK\%C3\%93W\%20NIERUCHOMYCH.pdf

Szmygin, B., Fortuna-Marek, A. \& Siwek, A., Wartościowanie dziedzictwa w systemie SV - metoda i przykłady zastosowania, Lublin: Politechnika Lubelska, 2017.

Ustawa z dnia 23 lipca 2003 r. o ochronie zabytków i opiece nad zabytkami Dz. U. z 2021 r. poz. 710, 954, Art. 6. 1. 